\title{
The Influence of Transaction Cost and Service Quality on Partner Loyalty - the mediating effect of relationship quality
}

\author{
Chihmin Ma ${ }^{1, a}$, Guanwei Jang ${ }^{1}$ and Miaofen Lai ${ }^{2}$ \\ ${ }^{1}$ Guangdong University of science and technology, School of management, 523808 Guangdong, China \\ ${ }^{2}$ Overseas Chinese University, School of management, 40721 Taiwan, China
}

\begin{abstract}
This article puts forward the conceptual framework of supply chain partnership loyalty based on the relationship between transaction cost, service quality and relationship quality. The empirical study mainly focused on equipment purchasers, and a total of 321 valid samples were collected. The results show that 4 of the 9 hypotheses are not supported, namely Hypothesis H1c: the impact of information sharing on relationship quality, H2a: asset specificity, H2b: loyalty uncertainty and H5 loyalty relationship quality. Regarding the analysis of the mediating effect of relationship quality, this study found that relationship quality has a significant mediating effect in the relationship between asset specificity and loyalty or between service quality and loyalty. That is, by investing in exclusive assets and improving service quality, customers will not show better loyalty, but asset specificity and highquality services can affect loyalty through relationship quality.
\end{abstract}

\section{Introduction}

Supplier selection is very important for an organization to reduce operating costs and improve performance. If there is no suitable supplier to provide low-cost and highquality materials, it is bound to be unable to produce products or services that meet the needs of customers. Therefore, how to select suppliers carefully in the transaction process to maximize the benefits of procurement has become the key factor of organizational profitability.

Previous studies on supplier management often analyze inter-organizational relationships in the supply chain based on economic perspectives. Such as the use of transaction cost theory, resource dependence theory or agency cost theory. From a practical point of view, there is no doubt that the partnership between upstream and downstream sales and purchases is indeed an exchange of economic benefits. Various cost factors need to be considered in the transaction process. As the research of Young-Ybarra \& Wiersema [1] pointed out, transaction cost is a very useful point of view, which is usually used to measure the dimensions of strategic alliance members. However, in the transaction process, in addition to rational factors, implicit factors such as psychological emotions and trust are also usually included. Therefore, some scholars point out that mutual trust between partners is a necessary condition for maintaining the development of the alliance [2]. If there is high trust and strong commitment between partners in the supply chain, it will be easier to achieve excellent cooperation performance [3].
The organization always expects to achieve the lowest cost with proper quality assurance, the overall operating cost and quality of the organization tend to be balanced. Therefore, if the organization expresses satisfaction with the quality of service provided by the supplier. High service quality can usually bring high satisfaction and trust to the organization, thereby enhancing loyalty. The research of Henning-Thuran \& Klee [4] believes that the basis of any sales relationship is to build on the exchange of services or products. Transaction costs exist in the buying and selling, which are related to the quality of the relationship. The gap between organizations and suppliers in their understanding of market information and supply information will cause difficulties in the management of inter-organizational channels, which is basically one of the important reasons for transaction costs. The inconsistency of corporate goals will also lead to suspicion of mutual trust relationships, and the lack of a trustworthy supplier relationship often makes every transaction must be reviewed and verified. Insufficient trust will cause most decision makers to spend considerable time analyzing the reputation, reliability and trustworthiness of trading partners.

According to the above discussion, this study will combine the concepts of transaction cost and relationship quality to explore the loyalty behavior of supply chain partnerships. Use Structural Equation Modeling (SEM) to discuss the relationship between transaction costs, service quality and loyalty, and further discuss the mediation of relationship quality.

\section{Literature review}

\footnotetext{
a Corresponding author: ordc99@yahoo.com.tw
} 


\subsection{Transaction cost theory}

Transaction cost theory (TCT) was first proposed by Coase. It believed that the uncertainty of the environment and bounded rationality would distort the operation of market functions and lead to transaction costs. According to Coase's idea that transaction costs are caused by incomplete contracts, that is, when buyers and sellers conduct a transaction, in addition to the purchase price, there are two types of transaction costs implied before and after. Because of the uncertainty of the environment, under unpredictable and complex and volatile conditions, manufacturers will try to develop a response mechanism to reduce the difficulty of adapting. As a result, the cost of prior contract negotiation and adaptation, such as the cost of information collection, agreement negotiation, and contract guarantee, has been increased. The uncertainty of behavior comes from the difficulty of monitoring the counterparty's execution of the transaction. When the two parties in a transaction are in the situation of uncertainty and information asymmetry, they are more prone to opportunistic behavior, and opportunism will make decision-makers seek the best decision according to their own interests.

However, it is actually difficult and costly to confirm opportunistic behavior beforehand, but if it is discovered afterwards, it may have suffered losses, and the cost of monitoring and executing the contract must be considered after the transaction. In short, the so-called transaction cost refers to all the costs that do not directly occur in the production process. People want to complete the transaction activities in the most economical way. The company's profit must be maximized when the cost is the smallest.

Because the transaction cost theory can more accurately interpret the structure of transaction behavior. Therefore, it has recently been used by many scholars to evaluate the relationship between supply chains. From a long-term perspective, if the transaction cost theory model is introduced into the company's strategic management, it will also help the company's development and decision-making.

The previous research aspects of transaction costs are mostly based on Williamson's [5] viewpoint, that is, from the three aspects of asset specificity, uncertainty, and transaction frequency. However, in the research of Kwon and Suh [3] discussing supplier partnership with transaction cost theory, they believe that information sharing should be a key element of supply chain relationship. Therefore, the measurement variables of transaction costs are excluded from transaction frequency, and the dimensions are revised into three items: asset specificity, uncertainty and information sharing.

\subsection{Service quality}

The research of Henning-Thuran \& Klee [4] pointed out that any sales relationship is established on the basis of service or product exchange. During the transaction, the buyer's perception of the overall quality of products and services is the basic element of establishing service quality. Because, service quality is not an absolute concept. Compared with physical goods, the difference between services and tangible goods is based on four unique characteristics--intangibility, inseparability of production and consumption, heterogeneity, and perishability. Service is a relatively abstract and elusive generalization. Whether customers are satisfied with the service quality of the enterprise is determined by the comparison of the customer's expectation and afterthought. If the service provided by the enterprise exceeds the customer's expectations in advance, the customer will show a higher degree of satisfaction. If the customer feels that there is a gap with the expectations afterwards, it will be unsatisfactory.

Service quality is manifested by the perception continuum [6]. It is the result of the comparison between pre-purchase expectation and post-perception. Therefore, Parasuraman et al. [7] defined service quality as the gap between the expected level of service provided and the perceived level of service actually perceived by customers. If the gap between the two is larger, it means that the service quality is lower, and vice versa. Parasuraman et al. $[7,8]$ used perceptual service to measure service quality, and developed a SERVQUAL model with five major factors including tangibles, reliability, responsiveness, assurance and empathy. It has been widely used in practical fields and has made considerable academic contributions.

\subsection{Relationship quality}

The concept of relationship quality originated from relationship marketing. It is a transaction-based marketing model that can improve the relationship performance between each other. Smith [9] defines relationship quality as the overall strength of various positive relationship result and the degree of satisfaction of the needs and expectations of the related person. According to the definition, the relationship quality can be used as a measure of the strength of the relationship.

Previous studies have not reached a consistent conclusion on the dimension of relationship quality, but many scholars agree that trust and commitment are two very important factors $[9,10]$. As Su et al. [11] pointed out, unsuccessful partnerships are due to the lack of trust in each other, therefore, if the transaction is not based on trust, both parties will spend a lot of time analyzing and understanding each other's reliability and trustworthiness. Leonidou et al. [12] also mentioned that trust in partners means wanting to develop and maintain relationships with partners. Trust can also establish commitment to each other; without commitment, partnerships become fragile and vulnerable. Therefore, the aspect of relationship quality in this study adopts two factors: trust and commitment.

\subsection{Loyalty}

Loyalty refers to the willingness to re-patronize or repurchase a favorite product or service [13]. Although the distinction of loyalty has many different degrees, scholars have different methods of measuring this 
concept. Customer loyalty can be divided into behavioral loyalty and attitude loyalty. Behavioral loyalty emphasizes repeated purchase behavior. Attitude loyalty emphasizes that in addition to repeated purchase behavior, customers have positive emotions toward suppliers, generate positive word-of-mouth sales, and recommend products or services of this supplier to others, and encourage them to use it.

Jones and Sasser [14] believe that customer loyalty can be divided into long-term loyalty and short-term loyalty. Long-term loyalty will show the long-term purchase and consumption of a certain brand, and it is not easy to change the consumer items, which represents the customer as the real loyalty. Short-term loyalty means that once the customer has a better choice, he will immediately change the previously consumed item or brand. The definition of loyalty in this study mainly adopts loyalty in attitude, which is a repeated purchase behavior. It has a positive sentiment towards the supplier and is willing to recommend the supplier's products or services and encourage others to use it.

\section{Theoretical Framework and Hypotheses Development}

This study will study four variables: transaction cost, service quality, relationship quality and loyalty in the purchasing department in Taiwan. In this model, transaction cost and service quality have a direct impact on loyalty, and it can also indirectly affect loyalty through relationship quality. Based on the inferences from the literature review, this study puts forward nine hypotheses and constructs an overall causal model. The theoretical framework guiding the investigation is depicted in figure 1 below.

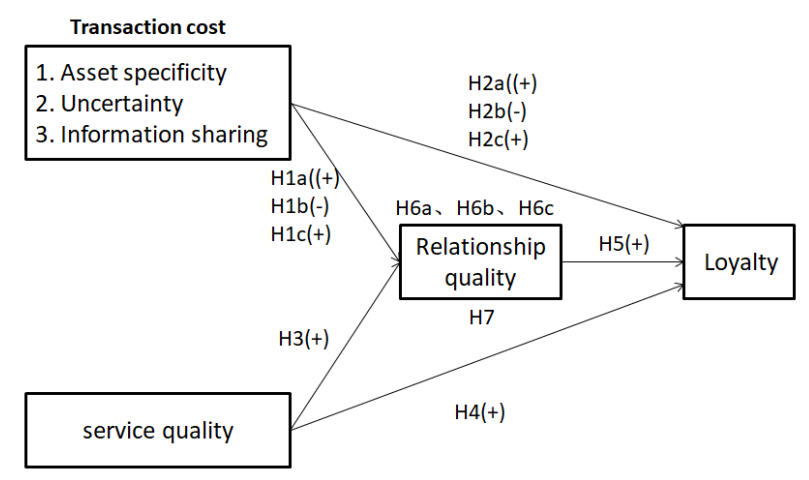

Figure 1. Conceptual Model

\subsection{Transaction cost and relationship quality}

Zhao et al. [15] found that if a company has a better transaction relationship with its customers, it has a positive impact on the customer's relationship quality. This will continue to increase the willingness to cooperate with the company. Exclusive assets between partners will affect the ability of supply chain integration. When partners are willing to make specific investments and combine each other's unique resources, they will be satisfied with low total value chain costs, thereby enhancing the trust relationship between the two parties [3]. Therefore, when the investment in specific assets increases, partners will be hesitant to terminate the relationship. This expectation of the continuity of the relationship between the two parties has a positive relationship.

Uncertainty makes the partner feel uneasy, and then doubts the partner and reduces trust. Therefore, Kwon \& Suh [3] pointed out that trust is a key factor that promotes supply chain cooperation and commitment between partners. The specific asset investment (positive effect) and uncertainty (negative effect) of both partners have an impact on the relationship quality of the supply chain. In addition, many scholars mentioned that information sharing is a very important key factor in the integration of buying and selling relationships. Information sharing can reduce uncertainty and increase the trust between supply chain partners and encourage partners to make good decisions [3]. This study mainly discusses three aspects of transaction cost: asset specificity, uncertainty and information sharing. The hypothesis of the relationship between transaction cost and relationship quality is as follows:

H1a: Asset specificity positively affects the relationship quality.

H1b: Uncertainty negatively affects the relationship quality.

H1c: Information sharing positively affects relationship quality.

H2a: Asset specificity positively affects loyalty.

$\mathrm{H} 2 \mathrm{~b}$ : Uncertainty negatively affects loyalty.

$\mathrm{H} 2 \mathrm{c}$ : Information sharing positively affects loyalty.

\subsection{Service quality 、 relationship quality and loyalty}

Crosby et al. [16] pointed out that service quality is a necessary condition for relationship quality. If a serviceoriented industry can provide customers with high service quality, it can bring customers high satisfaction and trust, thereby enhancing their loyalty. In addition, Boulding et al. [17] proposed that service quality has a positive impact on customer loyalty. Hence the hypothesis; H3: Service quality positively affects relationship quality. H4: Service quality positively affects loyalty.

\subsection{Relationship quality and loyalty}

The discussion of relationship quality in this study has consolidated the two dimensions of trust and commitment. In the subsequent analysis, trust and commitment will be integrated into a dimension of relationship quality. Relationship quality is to use the method of relationship sales to build a good relationship with customers, to reduce the certainty of customer interactions $[16,18]$. A study by Schurr \& Ozanne [19] found that trust affects consumers' attitudes and behavior towards manufacturers. Customer satisfaction and trust affect customer loyalty. At the same time, trust is also a key mediator before and after purchase. It can lead to long-term customer loyalty. 
On the other hand, Moorman et al. [20] point out that customers who have a loyal relationship are more willing to maintain a relationship with the company. Customers who have a high degree of loyalty will be willing to work with the company based on the past acceptance. As inferred from the above literature, this study puts forward the following hypotheses:

H5: Relationship quality will positively affect the perception of supplier loyalty.

\section{Research Methodology}

\subsection{Sample and Respondent Profile}

The target population is three large medical institutions in Taiwan. Questionnaires were distributed to all medical equipment purchasers in the institution. A total of 1,000 questionnaires were distributed and 352 were collected. After deducting 31 invalid responses such as incomplete and regular responses, a total of 321 valid responses were recovered, and the effective response rate was $32.1 \%$. The average age of the effective sample is 36.14 years. The majority of respondents are $245 \quad(76.3 \%)$ undergraduates. The executive level is $84(26.2 \%)$. With more than 10 years of service, $110(34.3 \%)$ is the most, and more than 5 years is $200(62.3 \%)$. The age distribution, education level, and years of service of the sample show that the respondents are qualified to answer the questionnaire.

\subsection{Measurement Instrument and Questionnaire Design}

The conceptual framework of this study includes the aspects of transaction cost, service quality, relationship quality and loyalty. There are 6 variables to be measured, including 4 exogenous variables: transaction cost (asset specificity, uncertainty, information sharing) and service quality, and 2 endogenous variables: relationship quality and loyalty. Appropriate definitions of variables and development of measurement tools based on the literature. Except for the demographic variables of the questionnaire, which are measured by nominal scale, the rest of the dimensions are all measured by Likert 7-point ordinal scales. Variable measurement methods are shown in Table 1 .

\section{Data Analysis}

\subsection{Structural Equation Modelling Approach}

This study uses partial least squares (PLS) as an analysis technique to detect or construct predictive models. Use SmartPLS software to carry out structural equation modelling to understand the relationship strength and direction between latent variables. SmartPLS is a regression-based technology derived from path analysis. Smart PLS has become a powerful method for studying causal models. It can involve multiple constructs with multiple indicators, and can model latent constructs that are not contaminated by measurement errors under nonnormal conditions.

Table 1. Variable measurement methods

\begin{tabular}{|c|c|}
\hline Dimension & Variable item \\
\hline $\begin{array}{l}\text { Transaction } \\
\text { cost }\end{array}$ & $\begin{array}{l}\text { The transaction cost questionnaire is divided } \\
\text { into three dimensions: asset specificity, } \\
\text { uncertainty and information sharing, with a total } \\
\text { of } 18 \text { items }[3,21] \text {. }\end{array}$ \\
\hline $\begin{array}{l}\text { Service } \\
\text { quality }\end{array}$ & $\begin{array}{l}\text { According to Parasuraman et al. [7,8] the } \\
\text { SERVQUAL model was developed with the } \\
\text { concept of perceptual quality. The model has } \\
\text { been well established as a tool for measuring } \\
\text { and tracking service quality. } \\
\text { In this study, the SERVQUAL questionnaire was } \\
\text { discussed in a single dimension, with } 22 \text { items } \\
\text { in total. }\end{array}$ \\
\hline $\begin{array}{l}\text { Relationship } \\
\text { quality }\end{array}$ & $\begin{array}{l}\text { This study refers to Crosby et al. [16], Kwon \& } \\
\text { Suh [3] to design a trust questionnaire. } \\
\text { Reference scholars designed a commitment } \\
\text { questionnaire. There are } 12 \text { questions about } \\
\text { relationship quality. }\end{array}$ \\
\hline Loyalty & $\begin{array}{l}\text { This study adopts the research results of } \\
\text { Gronholdt et al.[22] to measure the behavioral } \\
\text { loyalty and attitude loyalty. Use repurchase } \\
\text { willingness, recommended behaviors to others, } \\
\text { price tolerance, willingness to cross-buy, etc. as } \\
\text { indicators of loyalty, a total of } 8 \text { questions. }\end{array}$ \\
\hline
\end{tabular}

\subsection{Measurement Model}

To verify whether the reliability and validity of the causal model meets the test indicators. Use SmartPLS 2.0 statistical software to analyse the received questionnaire data. Reliability test results show that factor loading is between 0.519 and 0.904 , all of which are greater than 0.5 . The Cronbach's $\alpha$ of each facet is between 0.683 and 0.946. Although the uncertain facet is less than 0.7 (Cronbach's $\alpha=0.683$ ), it is very close and is still an acceptable value. The Composite Reliability (CR) value is between 0.824 and 0.953 , which is also greater than 0.8 . Average Variance Extracted (AVE) ranges from 0.534 to 0.719 , both of which are above 0.5 . Based on the above test results, it is obvious that the internal consistency of each dimension has roughly met the measurement indicators. This result is sufficient to infer that the scale of this study has good reliability.

In terms of validity test, the AVE value of each facet is above 0.5 , indicating that it has met the requirement of convergence validity. In addition, the square roots of AVE of the related facet are larger than the correlation coefficients between the facet and other facets. It can be verified that there is sufficient distinguishing ability between each aspect. Therefore, it can be inferred that the questionnaire compiled by this study also has good validity.

\subsection{Path Model}

The analysis results of standardized path coefficient $(\beta), t$ value, and explanatory variation $\left(\mathrm{R}^{2}\right)$ among the various aspects of the study model are shown in Figure 2. 
Among nine hypotheses, except four hypotheses are not supported. Hypothesis H1c information sharing versus relationship quality $(\beta=0.028)$. Hypothesis $\mathrm{H} 2 \mathrm{a}$ and $\mathrm{H} 2 \mathrm{~b}$ asset specificity, uncertainty to loyalty $(\beta-0.039$ and 0.065 respectively) and H5: relationship quality to loyalty $(\beta=0.131)$. The remaining five hypotheses all met the significance level $(\alpha=0.05)$. The interpretation ability of each endogenous latent variable $\left(R^{2}\right)$. relationship quality $R^{2}=0.680$ and loyalty $R^{2}=0.320$.

The path coefficient $(\beta), t$ value and hypothesis test of each aspect are summarized in Table 2.

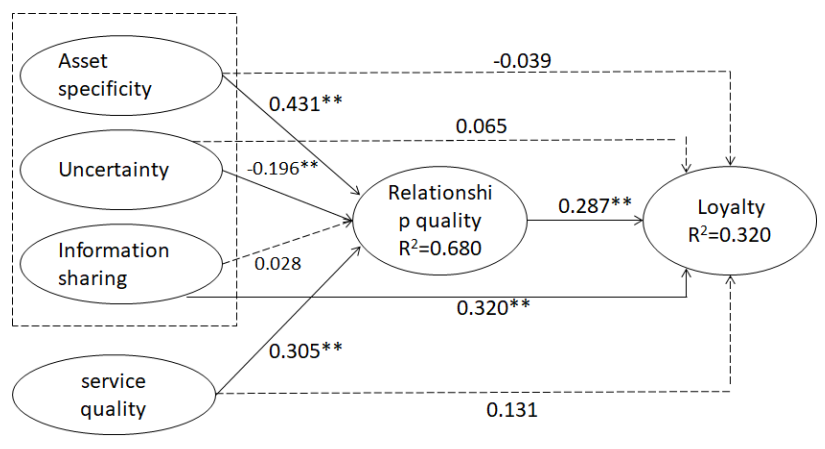

Figure 2. Path analysis of conceptual model (path coefficient $(\beta), t$ value and explanatory variation $\left.R^{2}\right) * p<0.05, * * p<0.01$

Table 2. Research hypothesis test results

\begin{tabular}{|c|c|c|c|}
\hline Hypothesis & $\begin{array}{c}\text { Causal } \\
\text { relationship }\end{array}$ & $\begin{array}{c}\begin{array}{c}\text { Path } \\
\text { coefficient } \\
\text { (t value) }\end{array} \\
\end{array}$ & Result \\
\hline H1a & $\begin{array}{l}\text { asset specificity } \\
\rightarrow \text { relationship quality }\end{array}$ & $\begin{array}{l}0.431 * * \\
(9.16)\end{array}$ & Supported \\
\hline $\mathrm{H} 1 \mathrm{~b}$ & $\begin{array}{l}\text { uncertainty } \\
\rightarrow \text { relationship quality }\end{array}$ & $\begin{array}{l}-0.196 * * \\
(3.53) \\
\end{array}$ & Supported \\
\hline $\mathrm{H} 1 \mathrm{c}$ & $\begin{array}{l}\text { information sharing } \\
\rightarrow \text { relationship quality }\end{array}$ & $\begin{array}{c}0.028 \\
(0.63)\end{array}$ & Rejected \\
\hline $\mathrm{H} 2 \mathrm{a}$ & $\begin{array}{l}\text { asset specificity } \\
\rightarrow \text { loyalty }\end{array}$ & $\begin{array}{c}-0.039 \\
(0.56)\end{array}$ & Rejected \\
\hline $\mathrm{H} 2 \mathrm{~b}$ & $\begin{array}{l}\text { uncertainty } \\
\rightarrow \text { loyalty }\end{array}$ & $\begin{array}{l}0.065 \\
(0.87)\end{array}$ & Rejected \\
\hline $\mathrm{H} 2 \mathrm{c}$ & $\begin{array}{l}\text { information sharing } \\
\rightarrow \text { loyalty }\end{array}$ & $\begin{array}{l}0.320^{* *} \\
(3.58)\end{array}$ & Supported \\
\hline H3 & $\begin{array}{l}\text { service quality } \\
\rightarrow \text { relationship quality }\end{array}$ & $\begin{array}{l}0.305^{* *} \\
(5.34) \\
\end{array}$ & Supported \\
\hline H4 & $\begin{array}{l}\text { relationship quality } \\
\rightarrow \text { loyalty }\end{array}$ & $\begin{array}{l}0.287 * * \\
(7.15)\end{array}$ & Supported \\
\hline H5 & $\begin{array}{l}\text { service quality } \\
\rightarrow \text { loyalty }\end{array}$ & $\begin{array}{c}0.131 \\
(1.11)\end{array}$ & Rejected \\
\hline
\end{tabular}

\section{Discussion of Results}

\subsection{The impact of transaction cost on relationship quality}

Asset specificity and uncertainty have a significant impact on relationship quality ( $\beta=0.431,-0.196$ ), and hypothesis $\mathrm{H} 1 \mathrm{a}$ and $\mathrm{H} 1 \mathrm{~b}$ are supported. This shows that the more exclusive assets a supplier invests in it, the more trust the organization will feel. Uncertainty will make partners feel uneasy, and then doubt the partners and reduce trust. The relationship between information sharing and relationship quality is not significant, that is, the H1c hypothesis is not supported. The inference may be that most of the information is already based on established business processes. In the process of correct transactions, both parties rely more on the links of network information, and informal information sharing will not have a significant effect on the development of the relationship quality of both parties.

\subsection{The impact of transaction cost on loyalty}

Information sharing has a significant impact on loyalty $(\beta=0.320)$. The clearer the representative information is conveyed, the easier it is for the organization to grasp the trends of the traded items. It is more likely that there will be repeated purchases. As for, asset specificity and uncertainty have no direct significant influence on loyalty, which will be discussed in the subsequent mediation effect.

\subsection{The relationship between service quality and relationship quality and loyalty}

Service quality has a significant effect on relationship quality $(\beta=0.305)$, and relationship quality also has a significant effect on loyalty $(\beta=0.287)$, which supports hypotheses $\mathrm{H} 3$ and $\mathrm{H} 4$. This result is consistent with the study of Crosby et al. [16]. Service quality is a necessary condition for relationship quality. If you feel high service quality, you will have higher satisfaction and trust, thereby enhancing its loyalty. However, service quality is not significant for loyalty $(\beta=0.131)$, indicating that hypothesis H5 is not supported. With high service quality, customers may not show a loyal attitude.

\subsection{Direct, indirect and mediating effects}

\subsubsection{Direct and indirect effects}

This study further explores the direct effects, indirect effects and total effects among various variables. Clarify the causal model between exogenous and endogenous. Study shows that in addition to the direct effect of the research model, for the linear structural equation model, the total effect formed by the direct and indirect effects of other latent variables must be considered. The direct effect, indirect effect and overall effect of each latent variable in this study are shown in Table 3.

Since the analysis results of the structural model show the indirect effect of the relationship quality, it is impossible to determine the influence of the relationship quality in the model. For example, the total effect of asset specificity on relationship quality $(0.431)$ is the largest, but the total effect of asset specificity on loyalty through relationship quality is only 0 . 085.In fact, the total effect $(0.085)$ of asset specificity on loyalty is the result of the direct effect $(-0.039)$ plus the indirect effect $(0.124)$. Therefore, the direct and indirect effects on the meaning of the independent variable and the dependent variable 
shall be further explored based on the intermediary analysis.

Table 3. Direct, indirect effects and total effects

\begin{tabular}{|c|c|c|c|c|c|}
\hline \multicolumn{2}{|c|}{ Variable relationship } & \multirow{2}{*}{$\begin{array}{l}\text { Direct } \\
\text { effects }\end{array}$} & \multirow{2}{*}{$\begin{array}{l}\text { Indirect } \\
\text { effects }\end{array}$} & \multirow{2}{*}{$\begin{array}{l}\text { Total } \\
\text { effects }\end{array}$} & \multirow{2}{*}{ t value } \\
\hline Endogenous & Exogenous & & & & \\
\hline \multirow{4}{*}{$\begin{array}{l}\text { Relationship } \\
\text { quality }\end{array}$} & $\begin{array}{l}\text { Asset } \\
\text { specificity }\end{array}$ & 0.431 & - & 0.431 & $9.16^{* *}$ \\
\hline & Uncertainty & -0.196 & - & -0.196 & $3.53 * *$ \\
\hline & $\begin{array}{l}\text { Information } \\
\text { sharing }\end{array}$ & 0.028 & - & 0.028 & 0.63 \\
\hline & \begin{tabular}{|l|} 
Service \\
quality
\end{tabular} & 0.305 & - & 0.305 & $5.34 * *$ \\
\hline \multirow{5}{*}{ Loyalty } & $\begin{array}{l}\text { Asset } \\
\text { specificity }\end{array}$ & -0.039 & 0.124 & 0.085 & 1.34 \\
\hline & Uncertainty & 0.065 & -0.056 & 0.009 & 0.12 \\
\hline & $\begin{array}{l}\begin{array}{l}\text { Information } \\
\text { sharing }\end{array} \\
\end{array}$ & 0.320 & 0.008 & 0.328 & $3.86^{* *}$ \\
\hline & \begin{tabular}{|l|} 
Service \\
quality
\end{tabular} & 0.131 & 0.088 & 0.209 & $2.17 * *$ \\
\hline & $\begin{array}{l}\text { Relationship } \\
\text { quality }\end{array}$ & 0.287 & 0.040 & 0.327 & $3.37 * *$ \\
\hline
\end{tabular}

\subsubsection{Mediation analyses of relationship quality}

According to the research of WEN Zhonglin \& YE Baojuan [23], they modified the causal steps approach of Baron \& Kenny [24]. Explain clearly the meaning of the model's intermediary variables, and solve the problem that the path coefficients of direct and intermediary have different signs. Therefore, this study is based on the research of WEN Zhonglin \& YE Baojuan [23] to discuss the mediating effect of relationship quality, and the related definitions of variables are shown in Figure 3. Using SmartPLS 2.0 software to directly verify the significance and $t$ value of the path with Bootstrap method, the analysis results are shown in Table 4. According to Table 4 and the definition of WEN Zhonglin \& YE Baojuan [23], the inferences of relationship quality regarding direct, indirect and mediating effects are as follows:

1. Relationship quality in the relationship between asset specificity and loyalty, $\quad \mathrm{c}=0.110 \quad(\mathrm{t}=2.01) \quad$ is significant, coefficient $\mathrm{a}$ and $\mathrm{b}$ are both significant, and $\mathrm{c}^{\prime}$ is not significant. This means that the significant impact of asset specificity on loyalty is due to the appearance of relationship quality. This result can be inferred that relationship quality has a completely mediating effect.

2. Relationship quality is in the relationship between uncertainty and loyalty. The coefficient $\mathrm{c}$ is not significant ( $\beta=0.039, \mathrm{t}=0.52$ ), which means that relationship quality has no mediating effect between uncertainty and loyalty. The coefficients $a$ and $b$ are both significant, while c'is not significant. Only the ratio of direct and indirect effects needs to be discussed. That is, indirect $/$ direct $=0.241 \times 0.285 / 0.082=83.76 \%$, indicating that the relationship quality has a higher indirect effect..

3. Relationship quality is in the relationship between information sharing and loyalty. The coefficient $\mathrm{c}=0.324$ $(\mathrm{t}=4.00)$ is significant. The corresponding coefficients $a=0.043$ and $b=0.285$, one of which is not significant, and $c^{\prime}$ is significant. It means that relationship quality has an indirect effect of $0.01(0.043 \times 0.285)$ and a direct effect of 0.343 , respectively.

4.The relationship between relationship quality and loyalty in service quality is regarded as a complete intermediary.

From the above inspection, we can find the relationship between asset specificity to loyalty or service quality to loyalty. Relationship quality does have the conditions for intermediary variables. Therefore, improving the awareness of relationship quality is the key to affect loyalty attitude in the model.

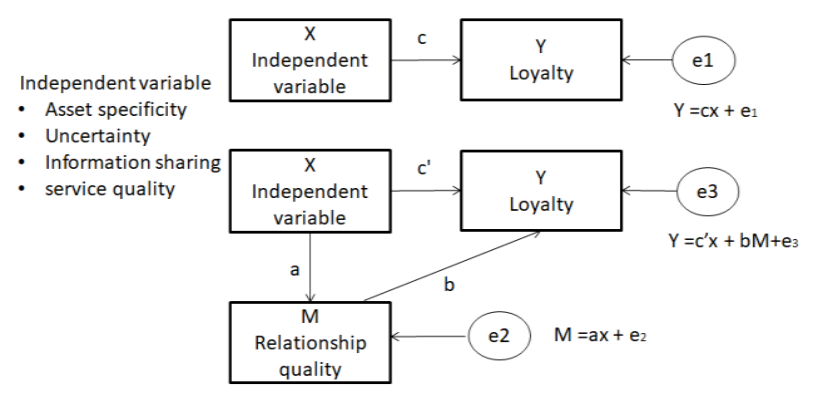

Figure 3. Schematic diagram of intermediary variables

Table 4. Mediation effect test of relationship quality

\begin{tabular}{|c|c|c|c|c|c|c|}
\hline \multicolumn{3}{|c|}{ Types of Variables } & \multicolumn{4}{|c|}{ Path coefficient (t-test) } \\
\hline IV & MV & $\overline{D V}$ & $\begin{array}{c}c \\
\text { (t-test) }\end{array}$ & $\begin{array}{c}\mathrm{a} \\
(\mathrm{t}-\mathrm{test})\end{array}$ & $\begin{array}{c}\mathrm{b} \\
(\mathrm{t}-\mathrm{test})\end{array}$ & $\begin{array}{c}\mathrm{c}^{\prime} \\
\text { (t-test) }\end{array}$ \\
\hline AS & \multirow{4}{*}{ RQ } & \multirow{4}{*}{ LO } & $\begin{array}{l}0.110 \\
(2.01)\end{array}$ & $\begin{array}{l}0.425 \\
(8.73)\end{array}$ & \multirow{4}{*}{$\begin{array}{l}0.285 \\
(3.25)\end{array}$} & $\begin{array}{r}0.011 \\
(0.19)\end{array}$ \\
\hline UC & & & $\begin{array}{l}0.039 \\
(0.52)\end{array}$ & $\begin{array}{r}-0.241 \\
(5.28)\end{array}$ & & $\begin{array}{l}0.082 \\
(1.10)\end{array}$ \\
\hline IS & & & $\begin{array}{l}0.324 \\
(4.00)\end{array}$ & $\begin{array}{c}0.043 \\
(0.96)\end{array}$ & & $\begin{array}{c}0.343 \\
(3.60)\end{array}$ \\
\hline SQ & & & $\begin{array}{l}0.247 \\
(2.86)\end{array}$ & $\begin{array}{l}0.282 \\
(5.30)\end{array}$ & & $\begin{array}{c}0.149 \\
(1.41)\end{array}$ \\
\hline
\end{tabular}

Abbreviation: Independent variable: IV; Mediation variable: MV; Dependent variable: DV; Asset specificity:AS;

Uncertainty: UC; Information sharing: IS ; Service quality:SQ; Relationship quality:RQ; loyalty: LO

\section{Conclusion}

This study uses PLS analysis technology to conduct empirical research on causal models. Mainly analyze the impact of transaction cost and service quality on loyalty. Also discuss the mediating effect of relationship quality. Nine Hypothesis are proposed in the model, and the test results are shown in Table 2. Among them, except for the four hypotheses, the other five hypotheses all reach the significant level $(\alpha=0.05)$.

Analysis of the mediating effect of relationship quality and the results of the research hypothesis in Table 2. Summarized as follows:

1. Neither asset specificity nor service quality has a direct significant impact on loyalty. That is, customers who invest in exclusive assets and improve service quality will not show better loyalty. However, asset 
specificity and service quality can influence loyalty (mediating effect) through relationship quality. Therefore, if you want to improve customer loyalty through asset specificity and service quality, you must pay special attention to the fact that it cannot be achieved without the intermediary influence of quality.

2. In the relationship between uncertainty, relationship quality and loyalty, uncertainty has no significant effect on loyalty $(\beta=0.065)$, and relationship quality has no mediation effect, and the indirect effect is negative value. Therefore, the sum of the direct and indirect effects will reduce the total effect and produce a masking effect.

3. In the relationship between information sharing, relationship quality and loyalty. On the one hand, information sharing has a significant impact on loyalty $(\beta=0.343)$, on the other hand, it produces a small amount of indirect effects through relationship quality, and the overall total effect is significant $(\mathrm{t}=3.86)$.

\section{References}

1. Young-Ybarra, Candace and Wiersema. Margarethe Strategic Flexibility in Information Technology Alliances: the Influence of Transaction Cost Economics and Social Exchange Theory, Organization Science. 10(4), 439-459 (1999)

2. Johnson, J. L., Cullen, J. B., Sakano, T., Takenouchi, H. (1996). Setting the stage for trust and strategic integration in Japanese-U.S. cooperative alliances. Journal of International Business Studies, 27(5), 981 1004.

3. Kwon, I. -W. G., \& Suh, T.. Factors affecting the level of trust and commitment in supply chain relationships. Journal of Supply Chain Management. 40(2), 4-14 (2004)

4. Henning-Thuran, T. and Klee, K.. The impact of customer satisfaction and relationship quality on customer retention: A critical reassessment and model development. Psychology and Marketing. 14(8), 737-764 (1997)

5. Williamson, O. E.. The Economic Institutions of Capitalism. New York: The Free Press (1985)

6. Parasuraman, A., Zeithaml, V. A., \& Berry, L. L.. A conceptual model of service quality and its implications for future research. Journal of Marketing. 49 (4), 41-50 (1985)

7. Parasuraman, A., Zeithaml, V. A., \& Berry, L. L.. SERVQUAL: A multiple-item scale for measuring consumer perceptions of service quality. Journal of Retailing. 64(1), 12-40 (1988)

8. Parasuraman, A., Zeithaml, V. A., \& Berry, L. L.. Refinement and reassessment of the SERVQUAL scale. Journal of Retailing. 67(4), 420-450 (1991)

9. Smith, J. B.. Buyer-seller relationships: Bonds relationship management, and sex-type. Canadian Journal of Administrative Sciences. 15(1), 76-92 (1998a)

10. Fang, S.-R., Chang, Y.-S., \& Peng, Y.-C. (2011). Dark side of relationships: A tensions-based view. Industrial Marketing Management, 40(5), 774-784.
11. Su, Q., Song, Y., Li, Z., \& Dang, J. (2008). The impact of Supply chain relationship quality on cooperative strategy. Journal of Purchasing and Supply Management, 14(4), 263-272.

12. Leonidou Leonidas C., Dayananda Palihawadana, and Marios Theodosiou. An Integrated Model of the Behavioral Dimensions of Industrial Buyer-Seller Relationships. European Journal of Marketing. 40 (1-2), 145-73 (2006)

13. Liu, Chung-Tzer, Guo, Yi Maggie, Lee, Chia-Hui,. The effects of relationship quality and switching barriers on customer loyalty. International Journal of Information Management. 31(1), 71-79 (2011)

14. Jones, T. O. and Sasser, W. E.. Why Satisfied Customer Defect. Harvard Business Review. 73(6), 88-99 (1995)

15. Zhao, X. F. \& Roth, A. V.. Decision sciences research in China current status, opportunities, and propositions for research in supply chain management. Logistics, and Quality Management. Decision Sciences. 38(1), 39-80 (2007)

16. Crosby, J. A., Evans, K. R., \& Cowles, D., Relationship Quality in Services Selling: An Interpersonal Influence Perspective. Journal of Marketing. 54(3), 68-81 (1990)

17. Boulding, W., \& Kirmani, A., A consumer-side experimental examination of signaling theory. Journal of Consumer Research. 20(1), 111-123 (1993)

18. Smith, J. B.. Buyer-seller relationship: Similarity, relationship management and quality. Psychology \& Marketing. 15(1), 3-21 (1998b)

19. Schurr, P.H., \& Ozanne, J. L.. Influences on exchange process: buyers preconceptions of a seller trustworthiness and bargaining toughness. Journal of Consummer Research.11(4), 939-953 (1985)

20. Moorman, C., Deshpande, R. \& Zaltman, G.. Factors affecting trust in market research relationship. Journal of Marketing.1(57), 1, 81-101 (1993)

21. Cai, S., Jun, M. \& Yang, Z., Implementing supply chain information integration in China: The role of institutional forces and trust. Journal of Operations Managemen. 28(3), 257-268 (2010)

22. Gronholdt, L., Martensen, A. and Kristensen, K.. The relationship between customer satisfaction and loyalty: Cross-industry differences. Total Quality Management. 11(5), 509-516 (2000)

23. WEN Zhonglin, YE Baojuan. Analyses of Mediating Effects: The Development of Methods and Models[J]. Advances in Psychological Science, 22(5): 731-745 (2014)

24. Baron, R. M., \& Kenny, D. A., The moderatormediator variable distinction in social psychological research: Conceptual, strategic, and statistical considerations. Journal of Personality and Social Psycholog. 51, 1173-1182 (1986) 